\title{
CONJUGATION OF SULFOBROMOPHTHALEIN IN NEWBORN INFANTS AND CHILDREN
}

\author{
By M. F. VEST
}

(From the Children's Hospital, University of Basel, Switzerland)

(Submitted for publication August 15, 1961 ; accepted December 23, 1961)

It has been shown recently by several research groups (1-5) that part of sulfobromophthalein (BSP), after intravenous injection into humans and animals, is excreted in the bile in a conjugated form. BSP conjugates also have been demonstrated in serum and urine $(6,7)$. Evidence has been presented that the amino acids, glycine, glutamic acid, and cysteine, are present in the conjugates $(4,8,9)$. The peptide, glutathione, appears to be conjugated with $\operatorname{BSP}(8,10,11)$. The question as to how important conjugation is for BSP excretion has not been settled so far. It is clear, however, that conjugation is not essential for BSP secretion and that at least part of the BSP can be secreted in the free form. In liver disease the relative percentage of free BSP and various conjugates in bile, serum, and urine differs from the normal $(6,7,12)$.

Because the elimination of BSP is retarded in both full term (13-15) and premature infants (16-19) it seemed of interest to investigate the extent of BSP conjugation in these age groups. Because of the insufficient conjugation that leads to the diminished bilirubin excretion after birth $(20,21)$, a similar mechanism for the inadequate BSP clearance was considered possible.

\section{METHODS}

The appearance of BSP conjugates in the serum was studied by chromatograms from 10 newborn infants, 2 to 9 days old, with body weights between 2.5 and $4 \mathrm{~kg}$; and from 13 children, aged 2.5 to 15.5 years. After intravenous injection of $5 \mathrm{mg}$ of $\mathrm{BSP}$ per $\mathrm{kg}$ body weight, blood samples were drawn at designated intervals, generally $3,15,30$, and 45 minutes and sometimes later. In 7 newborn infants and 7 children duodenal fluid also was obtained and chromatographed. Starting with the BSP injection, the collecting tubes were changed generally every 15 minutes in the older children and every 30 minutes in the newborn infants, in an attempt to follow the sequence of BSP conjugation in the bile. When feasible, bile collection was continued for about 2 to 3 hours until 5 or 6 consecutive samples had been obtained.
Before proceeding with the chromatographic separation, the concentration of total BSP was measured in samples of serum and suitably diluted bile by the method of Hofmann and Oettel (22). In preparing the plasma and bile samples for BSP chromatography the procedure of Carbone, Grodsky and $\mathrm{Hjelte}$ (6) was followed. One to $2 \mathrm{ml}$ of serum or a sufficient amount of duodenal juice was extracted with 3 times the volume of acetone. More than 90 per cent of the BSP present is recovered in this way. The acetone extract was taken to dryness by a stream of air in a water bath at $40^{\circ} \mathrm{C}$, redissolved in water $(0.2 \mathrm{ml}$ for each $\mathrm{ml}$ of the initial sample), and chromatographed on Whatman $3 \mathrm{MM}$ paper in an ascending system using tert-butanol: water (1.73:1, vol/vol) for about 15 to 20 hours. Occasionally a system of $n$-butanol: glacial acetic acid: water $(8: 2: 2$, vol/vol) was used with Whatman no. 1 paper.

The different bands on the chromatograms were identified by a purple color upon exposure to ammonia fumes. Of the 23 serum chromatograms, 6 from infants and 4 from children could be estimated quantitatively for the percentage distribution of free BSP and BSP metabolites. Of 14 bile chromatograms, estimations could be made for 3 infants and 3 children. For that purpose the different areas were cut separately from the paper and macerated in 8 to $16 \mathrm{ml}$ of water. After centrifugation, $0.05 \mathrm{ml}$ of 1 per cent $\mathrm{NaOH}$ was added to an aliquot of the supernatant and the absorbance was measured against a blank at $575 \mathrm{~m} \mu$. The amount of BSP in each band was calculated by a BSP calibration curve from the absorbance of its eluate. The percentage of each BSP metabolite in a given sample of serum or bile was expressed in relation to the total amount of BSP present in all components of this sample. Possible differences in the absorption coefficient of different BSP metabolites were disregarded.

\section{RESULTS}

$B S P$ conjugates in the serum. The chromatograms of serum generally showed two, and occasionally three, bands. Figure 1 is a chromatogram of serum from samples taken $6,15,33$, and 60 minutes after BSP injection into an infant 4 days old. The fast component, with a mean $\mathrm{Rf}$ value of 0.83 , has the same mobility as pure, free BSP added to serum and identically processed. 


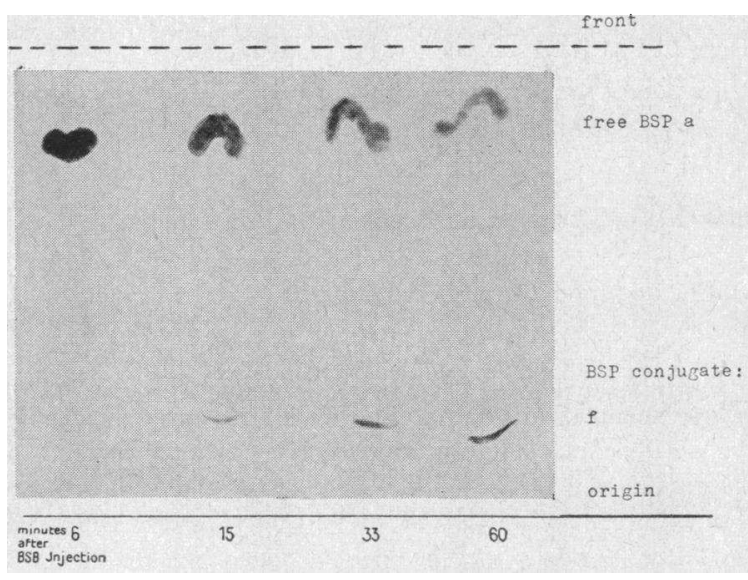

Fig. 1. Newborn infant, 4 days Old. Paper ChroMATOGRAM OF PIGMENTS IN SERUM SAMPLES TAKEN AT DIFFERENT TIMES AFTER BSP INJECTION.

The $\mathrm{Rf}$ value of the main slow component, $f$, varied between 0.15 and 0.29 in different chromatograms; the mean was 0.23 . This slow component already could be observed in some chromatograms 3 to 4 minutes after the i.v. administration of BSP; in other chromatograms it appeared only after 10,15 , or even 30 minutes.

Figure 2 is a BSP chromatogram in a 2.5 year



Fig. 2. Child, 2.5 years old. Chromatogram of PIGMENTS IN SERUM SAMPLES TAKEN AT DIFFERENT TIMES AFTER BSP INJECTION.

old child. The same two components are present as in the newborn infant. In this particular case the slow component, $f$, was visible for the first time in the blood sample taken 30 minutes after $\mathrm{BSP}$ injection. A third component, $\mathrm{b}^{\mathbf{1}}$ (Rf, 0.73), was present in three of the chromatograms in children and once, 53 minutes after BSP injection, in an infant. In two cases this component was present in addition to the usual BSP conjugate $f$

BSP-concentration in the serum at different times after i.v. injection showing

\section{free BSP and conjugates}

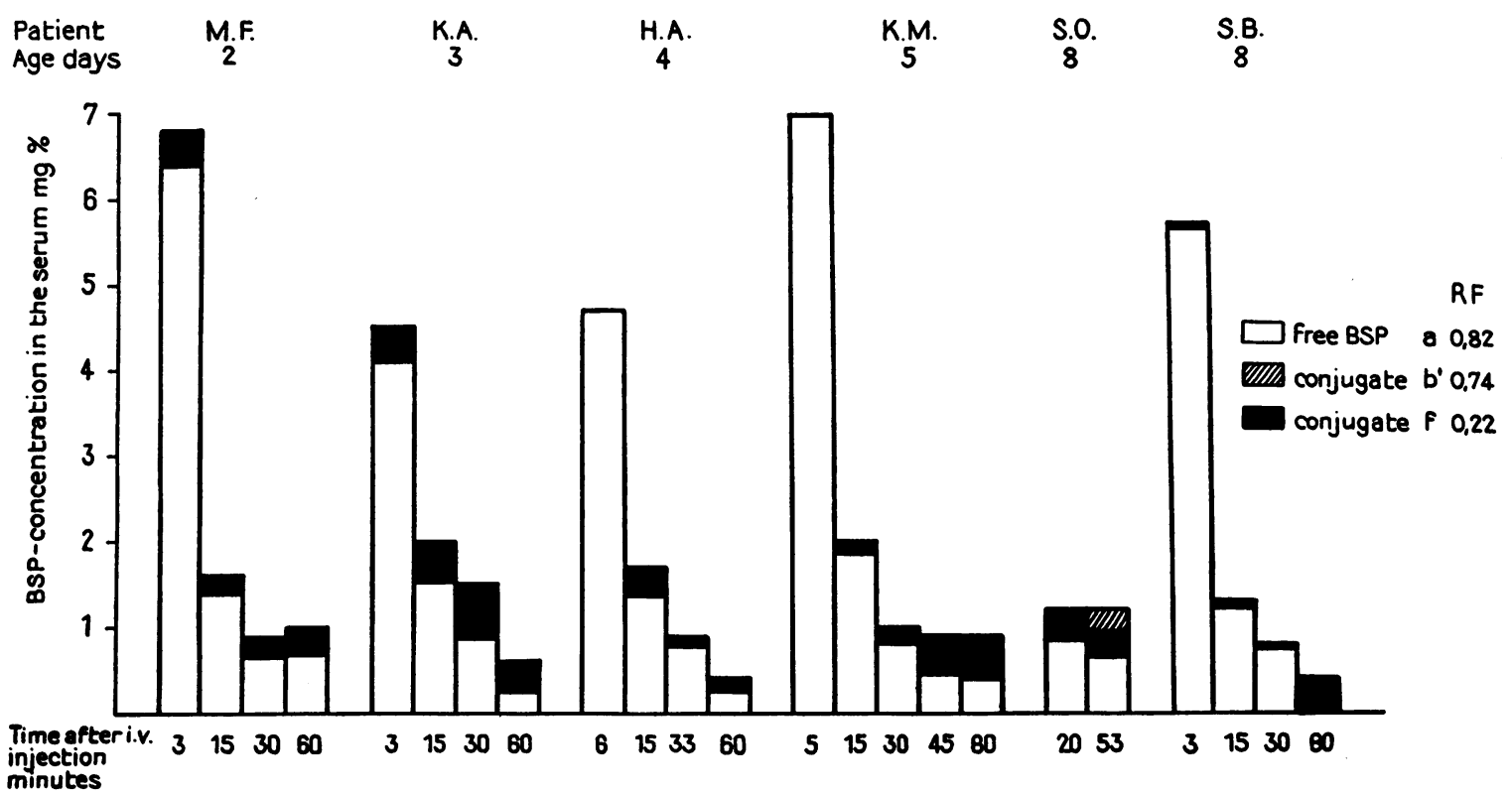

Fig. 3. Concentration of FREe AND CONJUgated BSP IN THE SERUM OF SIX NEwborn INFANTS AT SPECIFIC INTERVALS AFTER BSP INJECTION. 


$\begin{array}{llccc}\text { Patient } & \text { O.P. } & \text { L.A. } & \text { B.D. } & \text { S.C. } \\ \text { Ageyears } & 41 / 2 & 10 & 12 & 25 / 12\end{array}$

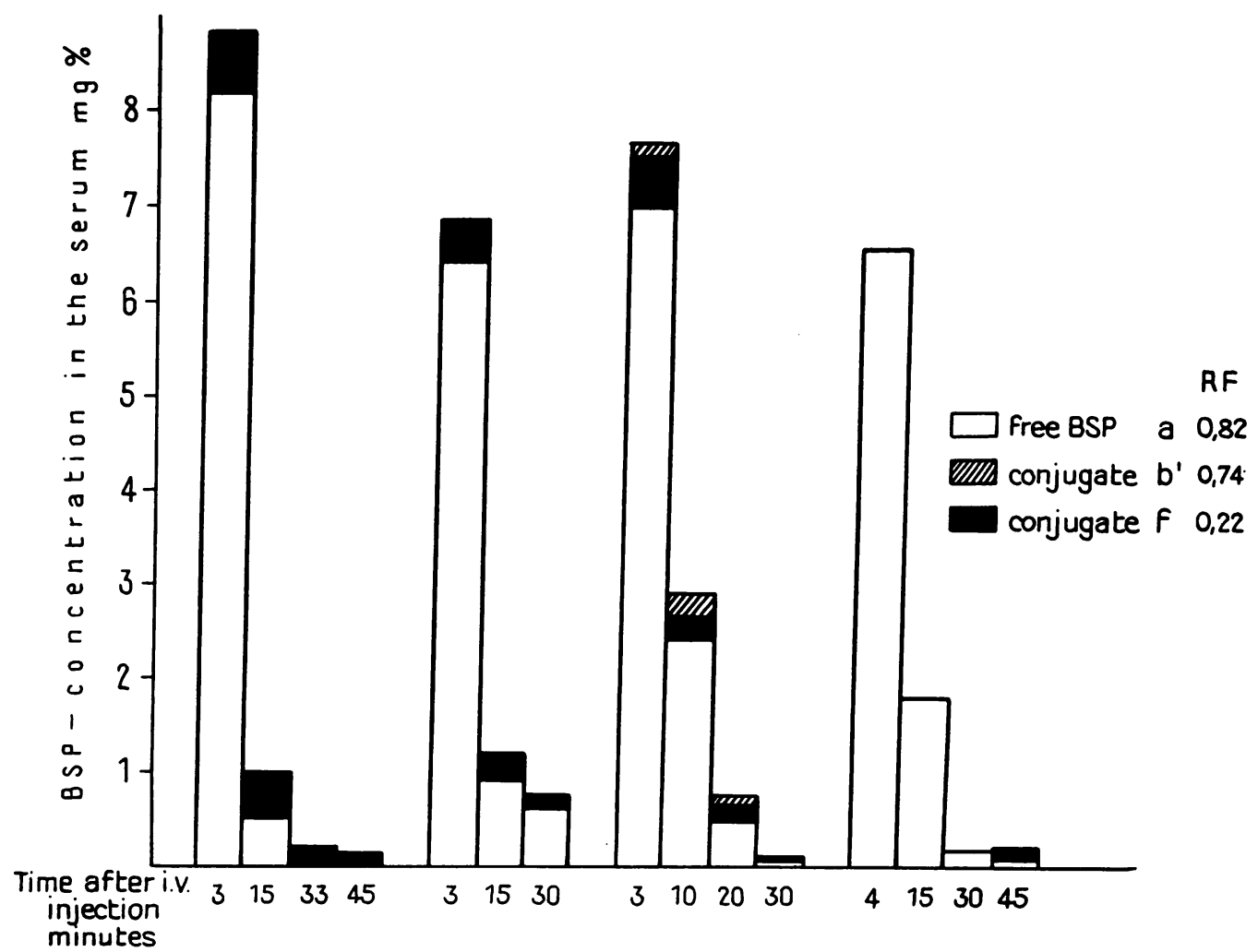

Fig. 4. Concentration of free and Conjugated BSP in the Serlim of four children at SPecific INTERVALS AFTER BSP INJECTION.

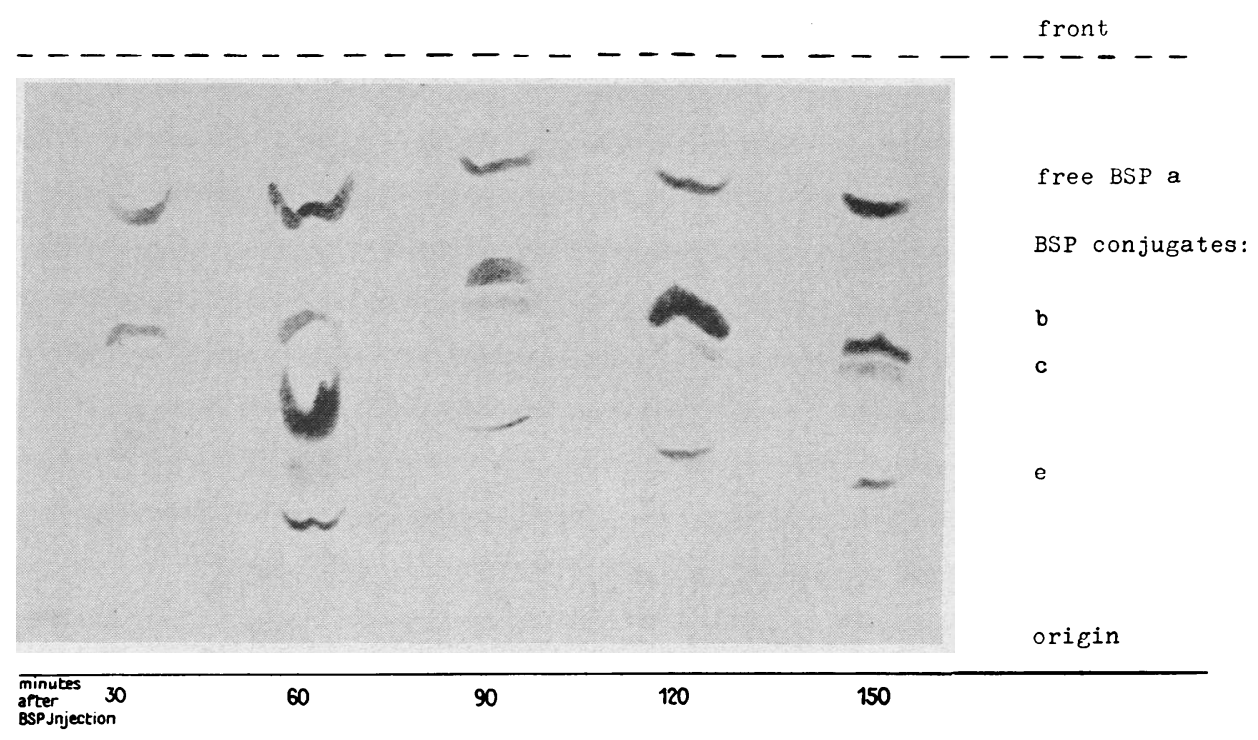

Fig. 5. Newborn infant, 4 days old. Chromatogram of pigments in samples of duodenal FLUid obtained AT Different times AFTER BSP injeCtion. 


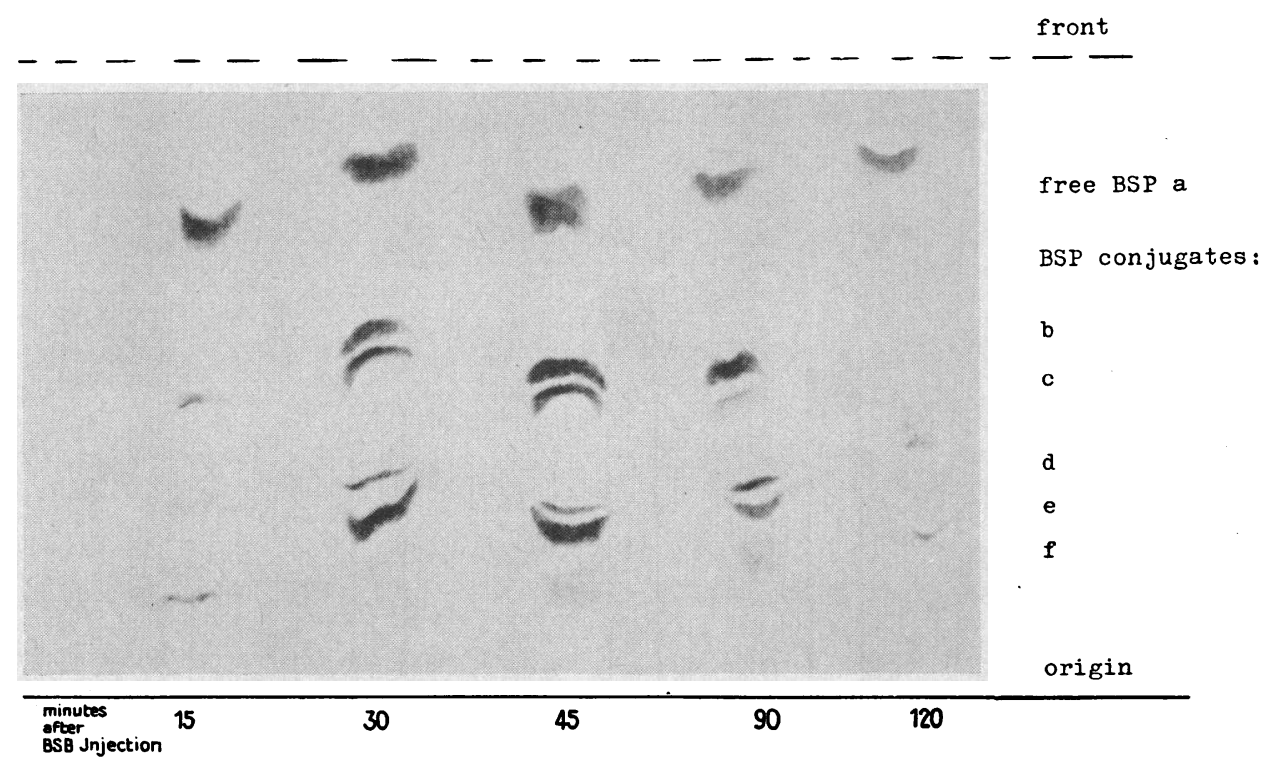

Fig. 6. Child, 4.5 years old. Chromatogram of pigments in samples of duodenal fluid OBTAINED AT DIFFERENT TIMES AFTER BSP INJECTION.

with an $\mathrm{Rf}$ of 0.23 . In the other two the conjugate $f$ was missing.

Figures 3 and 4 show the concentration of free $\mathrm{BSP}$ and $\mathrm{BSP}$ conjugates in the serum at specific intervals after the i.v. BSP injection in the six newborn infants and the four children whose chromatograms were analyzed for percentage distribution. The mean BSP retention 30 minutes after injection was 18 per cent in the newborns and 3.2 per cent in the children. No obvious differences between newborn infants and children are visible in the relative percentage of conjugated BSP metabolites or in the time of their appearance in the serum. The relative amount of conjugated BSP generally increased with decreasing total BSP level. In two children (O.P. and B.D.)

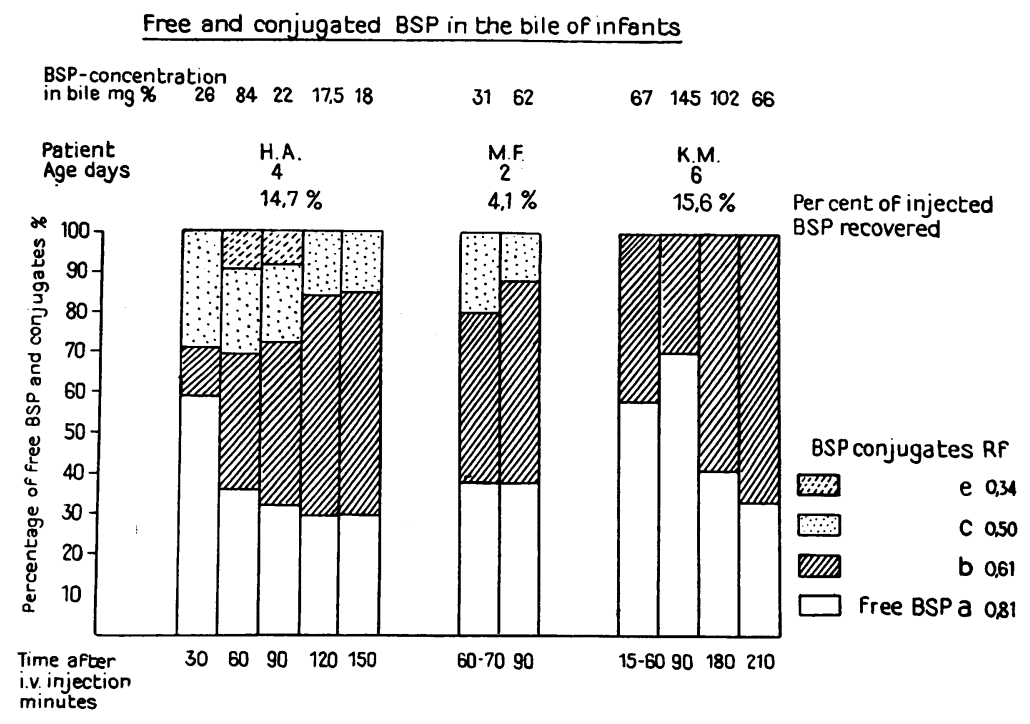

Fig. 7. Newborn infants; total BSP concentration and percentage DISTRIBUTION OF FREE BSP AND CONJUGATES IN CONSECUTIVE BILE SAMPLES OBTAINED AFTER I.V. INJECTION OF BSP. 
and in a newborn (S.B.), the samples taken 30 minutes or more after BSP injection contained only conjugated BSP. Two different conjugated metabolites were present in Child B.D. and Infant S.O. (53-minute sample).

$B S P$ conjugates in the duodenal fluid. Figures 5 and 6 are chromatograms obtained with acetone extracts of duodenal juice. Figure 5 concerns a 4 day old infant. In the first fraction collected during the 30 minutes after the BSP injection there are three bands. The fastest corresponds to free BSP, the two less polar bands are BSP metabolites. In the following samples four to five bands are visible. In the other chromatograms from newborn infants there are generally three to four, and occasionally only two, bands present. Figure 6 is a BSP chromatogram of a child 4.5 years old. At 6 minutes after BSP injection no spots are discernible on the paper. In the following samples five to six bands are visible (except in the last fraction where they are not clearly visible in the reproduction). As a rule, four to seven different bands could be distinguished on the chromatograms of children.

Figures 7 and 8 give the percentage distribution of the various bands, the total BSP concen- tration in consecutive bile samples, and the percentage of injected BSP recovered for those chromatograms that were eluted. The fastest component corresponding in mobility to free BSP with a mean $\mathrm{Rf}$ value of 0.82 was labeled $\mathrm{a}$. The metabolites called $\mathrm{b}, \mathrm{c}, \mathrm{d}$, e, and $\mathrm{f}$ had mean $\mathrm{Rf}$ values of $0.61,0.48,0.43,0.33$, and 0.23 and showed the same average mobility in infants and older children. The closely moving band $b$ was combined with $\mathrm{c}$, and $\mathrm{d}$ with $\mathrm{e}$, for the calculation of relative percentages of conjugates in some instances (cf Figure 8, Children W.G., S.C., and L.P.). As already mentioned there are fewer BSP conjugates present in the chromatograms of newborn infants (Figure 7) than in those of older children (Figure 8). Infant K.M., for instance. showed only free BSP and one conjugate. In both groups free BSP constituted the major part of the BSP present in the early samples, amounting to about 58 per cent in the infants H.A. and K.M. and 45 and 53 per cent in the children S.C. and L.P., respectively. The number and relative percentage of conjugated BSP metabolites increases in later samples in both age groups. The concentration of total BSP in the duodenal fluid tended to rise faster and to reach higher values in

Free and conjugated BSP in the bile of children

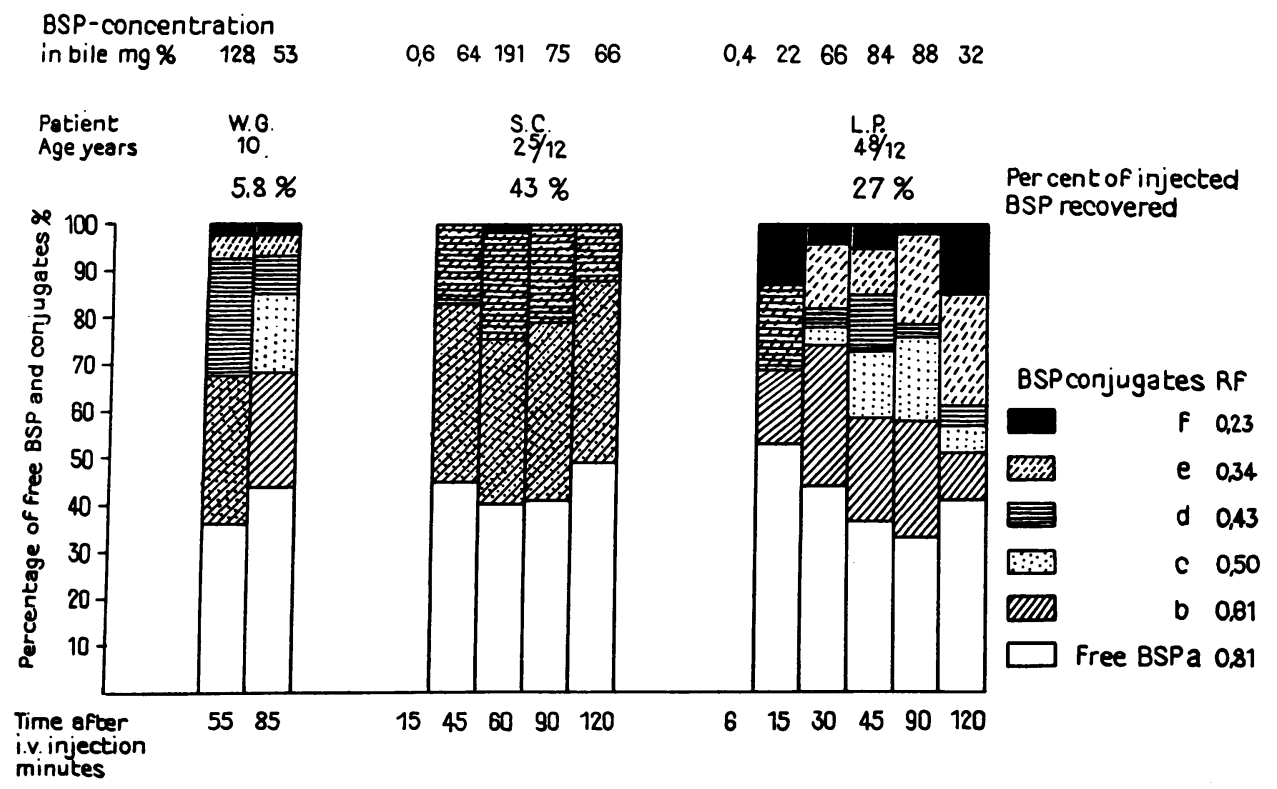

Fig. 8. Children; total BSP concentration and percentage distribution of free BSP AND CONJUGATES IN CONSECUTIVE BILE SAMPLES OBTAINED AFTER I.V. INJECTION OF BSP. 
the children than in the newborn infants; but these differences were not very pronounced. The recovery of BSP from the duodenal juice, expressed as percentage of dose injected, ranged from 4.1 to 15.6 in newborns and from 5.8 to 43 per cent in children. In a comparison of newborn infants and older children in whom duodenal fluid was obtained over an extended period of time (cf H.A. and K.M. in Figure 7, with S.C. and L.P. in Figure 8) the percentage of recovery was definitely lower in the newborn group. In the two infants, 14.7 and 15.6 per cent were recovered in 150 and 210 minutes, respectively, whereas in the children, 43 and 27 per cent were found during a collection period of 120 minutes.

\section{DISCUSSION}

Confirming the findings of other investigators (13-19) the present study shows that BSP retention in the serum is higher in the newborn period than in later life. It further indicates that the quantity of BSP recovered from bile (expressed as percentage of the amount of BSP injected) and, as a rule, the maximal BSP concentration reached in the duodenal fluid are lower in newborn infants. Several possibilities exist to explain this increased plasma retention and decreased delivery of BSP into the bile.

First, the uptake of BSP into the liver cells could be delayed, either because the ability of the cells to remove dye from the plasma or the rate of dye presentation (i.e., the sinusoid blood flow rate) is decreased. It has been shown that the typical plasma disappearance curve of BSP can be fitted by two exponential functions. The slope of the first of these functions reflects the rate at which dye is leaving the plasma to enter the liver (23). In young and older premature infants the first half of the BSP excretion curve in the plasma (slope I) does not differ much from that of adults (19). This makes it unlikely that diminished uptake is the cause of the increased BSP retention in newborn infants. The substantial amount of conjugated BSP often found in the serum shortly after BSP injection also suggests that uptake is unimpaired, because hepatic uptake presumably has to precede conjugation and seems to be relatively independent of this step (24). Theoretically some BSP could have been conjugated in extrahepatic tissues (25), but the enzyme activity in other organs is only a small fraction of that in the liver (26).

The second possibility is that impaired conjugation could be responsible for the BSP retention in the newborn period. A slight impairment cannot entirely be excluded on the basis of our results. On the other hand, newborn infants and older children showed the same number and percentage of BSP conjugates in the serum at a given time after BSP injection. In duodenal fluid, even though there were, as a rule, fewer different BSP conjugates visible, the percentage of conjugated $\mathrm{BSP}$, at least in later samples, was about the same, regardless of age. On the whole there is no great difference in the extent of BSP conjugation between newborn and older children. Impaired conjugation therefore seems unlikely as the chief cause of delayed BSP clearance in the newborn infant. This is somewhat in disagreement with the finding that, in vitro, the BSPconjugating activity of the liver is decreased in newborn rats (27).

In this connection one must remember that conjugation is not essential for BSP excretion, because free BSP is readily soluble and can be excreted in bile and urine. In this it differs markedly from the situation found in bilirubin excretion. Why some of the BSP is conjugated prior to excretion still is not clear. There is evidence that conjugated BSP can be secreted at a higher rate than is the free dye (24). On the other hand, a mixture of $\mathrm{BSP}$ metabolites disappeared more slowly from the plasma than did free BSP (4).

Because uptake and conjugation deficiencies seem unlikely, an insufficiency of the transport or secreting mechanism is the most probable cause of BSP retention in newborn infants. The observation that it is predominantly the second half of the plasma disappearance curve (slope II) that is altered (19) points in this direction, because it reflects the rate at which dye is passed from the liver to the bile (23).

The postulated deficiency of BSP secretion without demonstrable insufficiency of the conjugation process in newborn infants finds a parallel in the cases of chronic familial nonhemolytic jaundice with conjugated serum bilirubin of the DubinJohnson and Rotor variety, in which BSP reten- 
tion is also greatly increased, although conjugation seems to occur to a normal extent (28).

The question remains: to what extent are the conjugates of the newborn period identical with those seen in older children? The fact that the compounds show the same $\mathrm{Rf}$ values in two different solvent systems points in a positive direction. However, the final solution of the question must await the chemical analysis of the metabolites; this is at present under investigation. Results so far obtained (29), following the procedures outlined by Grodsky, Carbone and Fanska (8) and Combes (9), indicate the presence of the amino acids, glycine, glutamic acid, and alanine (or cysteine), in conjugates from both newborn and older children.

\section{SUMMARY}

In a group of 10 newborn infants 2 to 9 days old and in 13 older children up to age 15.5 years, samples of serum and duodenal juice obtained at specific intervals after the intravenous injection of $5 \mathrm{mg}$ sulfobromophthalein (BSP) per $\mathrm{kg}$ body weight were submitted to ascending chromatography for the estimation of free and conjugated BSP. Although BSP clearance from serum was markedly delayed in the newborn infants, the number of BSP conjugates, the time of their appearance, and the percentage of conjugates in relation to the total BSP concentration in serum or bile did not differ essentially in the newborn group from that observed in older children. From this and other findings it appears likely that the observed high BSP retention in the newborn period is not caused by a deficiency of the conjugation mechanism but points to an insufficiency of secretion.

\section{REFERENCES}

1. Krebs, J. S., and Brauer, R. W. Metabolism of sulfobromophthalein sodium (BSP) in the rat. Amer. J. Physiol. 1958, 194, 37.

2. Grodsky, G. M., Carbone, J. V., and Fanska, R. Metabolism of sulphobromophthalein. Nature (Lond.) $1959,183,469$.

3. Combes, B. Biliary excretion by the rat of Bromsulfalein as a conjugate of glycine and glutamic acid. Science 1959, 129, 388.

4. Meltzer, J. I., Wheeler, H. O., and Cranston, W. I. Metabolism of sulfobromophthalein sodium (BSP) in dog and man. Proc. Soc. exp. Biol. (N. Y.) $1959,100,174$.
5. de Fraiture, W. H., Heemstra, H., Vegter, J. J. M., and Mandema, E. Chromatographic separation of different Bromsulphalein metabolites in urine and bile. Acta med. scand. 1959, 165, 153.

6. Carbone, J. V., Grodsky, G. M., and Hjelte, V. Effect of hepatic dysfunction on circulating levels of sulfobromophthalein and its metabolites. J. clin. Invest. 1959, 38, 1989.

7. Higgins, F. E., Foulk, W. T., and Bollman, J. L. Column chromatography of bile, serum, and urine after intravenous administration of sulfobromophthalein. Gastroenterology 1960, 38, 194.

8. Grodsky, G. M., Carbone, J. V., and Fanska, R. Identification of metabolites of sulfobromophthalein. J. clin. Invest. 1959, 38, 1981.

9. Combes, B. The biliary excretion of sulfobromophthalein sodium (BSP) in the rat as a conjugate of glycine and glutamic acid. J. clin. Invest. 1959, 38, 1426.

10. Combes, B., and Stakelum, G. S. Conjugation of sulfobromophthalein sodium with glutathione in thioether linkage by the rat. J. clin. Invest. 1960, $39,1214$.

11. Javitt, N. B., Wheeler, H. O., Baker, K. J., Ramos, O. L., and Bradley, S. E. The intrahepatic conjugation of sulfobromophthalein and glutathione in the dog. J. clin. Invest. 1960, 39, 1570.

12. Mandema, E., de Fraiture, W. H., Nieweg, H. O., and Arends, A. Familial chronic idiopathic jaundice (Dubin-Sprinz disease), with a note on Bromsulphalein metabolism in this disease. Amer. J. Med. 1960, 28, 42.

13. Mollison, P. L., and Cutbush, M. Bromsulphalein excretion in the newborn. Arch. Dis. Childh. 1949, 24, 7.

14. Yudkin, S., and Gellis, S. S. Liver function in newborn infants with special reference to excretion of Bromsulphalein. Arch. Dis. Childh. 1949, 24, 12.

15. Herlitz, C. W. Rosenthal und Whites Leberfunktionsprobe (Bromsulphaleinprobe) bei Kindern unter einem Jahr und besonders bei Ikterus neonatorum. Acta paediat. (Uppsala) 1927, 6, 214.

16. Obrinsky, W., Denley, M. L., and Brauer, R. W. Sulfobromophthalein sodium excretion test as a measure of liver function in premature infants. Pediatrics 1952, 9, 421.

17. Perl, E. Untersuchungen über die Unreife der Leber bei Frühgeburten. Schweiz. med. Wschr. 1957, 87, 334.

18. Vest, M. Physiologie und Pathologie des Neugeborenenicterus. Basel, Karger, 1959.

19. Oppé, T. E., and Gibbs, I. E. Sulphobromophthalein excretion in premature infants. Arch. Dis. Childh. 1959, 34, 125.

20. Brown, A. K., and Zuelzer, W. W. Studies on the neonatal development of the glucuronide conjugating system. J. clin. Invest. 1958, 37, 332. 
21. Vest, M. Insufficient glucuronide formation in the newborn and its relationship to the pathogenesis of icterus neonatorum. Arch. Dis. Childh. 1958, 33, 473.

22. Hofmann, H. T., and Oettel, H. Die Leberfunktionsprüfung mit dem Bromsulphaleintest als einfache Mikromethode. Ärztl. Wschr. 1954, 9, 965.

23. Barber-Riley, G., Goetzee, A. E., Richards, T. G., and Thomson, J. Y. The transfer of Bromsulphthalein from the plasma to the bile in man. Clin. Sci. 1961, 20, 149.

24. Philp, J. R., Grodsky, G. M., and Carbone, J. V. Mercaptide conjugation in the uptake and secretion of sulfobromophthalein. Amer. J. Physiol. 1961, 200, 545.
25. Rosenau, W., Carbone, J. V., and Grodsky, G. M. Metabolism of sulfobromophthalein in hepatectomized and hepatectomized-nephrectomized dogs. Proc. Soc. exp. Biol. (N. Y.) 1959, 102, 131.

26. Combes, B., and Stakelum, G. S. A liver enzyme that conjugates sulfobromophthalein sodium with glutathione. J. clin. Invest. 1961, 40, 981.

27. Combes, B., and Stakelum, G. S. Maturation of liver enzyme that conjugates sulfobromophthalein sodium (BSP) and glutathione (abstract). J. clin. Invest. 1961, 40, 1030.

28. Vest, M. F., Kaufmann, H. J., and Fritz, E. Chronic non-haemolytic jaundice with conjugated bilirubin in the serum and normal liver histology: A case study. Arch. Dis. Childh. 1960, 35, 600.

29. Vest, M. F. Unpublished results. 